\title{
Observations on rock glaciers in the Himalayas and Karakoram Mountains of northern Pakistan and India
}

\author{
Lewis A. Owen ${ }^{\mathrm{a}, *}$, John England ${ }^{\mathrm{b}}$ \\ ${ }^{a}$ Department of Earth Sciences, University of California, Riverside, CA 92521-0423, USA \\ ${ }^{\mathrm{b}}$ Department of Earth and Atmospheric Sciences, 126 Earth Sciences Building, University of Alberta, Edmonton, Canada T6G 2 E3
}

Received 15 March 1996; revised 15 January 1997; accepted 1 March 1998

\begin{abstract}
Rock glaciers are abundant in the Lahul and Garhwal Himalayas of northern India and the Karakoram Mountains of northern Pakistan. They exhibit morainic and protalus forms and are restricted altitudinally and climatically to sites above approximately $4000 \mathrm{~m}$ asl. and regions where annual precipitation is less than $1000 \mathrm{~mm}$. In these areas, morainic rock glaciers are large, usually $>1 \mathrm{~km}$ long, $>100 \mathrm{~m}$ wide and $>15 \mathrm{~m}$ thick. They are advancing over recent fluvial terraces and modern floodplains. The morainic rock glaciers record the advance of ice-cored moraines following retreat of glaciers, likely since the Little Ice Age. These rock glaciers form a major component of the landscape and are important conveyors of debris down valley under the influence of gravity. (C) 1998 Elsevier Science B.V. All rights reserved.
\end{abstract}

Keywords: rock glaciers; Himalayas; Karakoram Mountains

\section{Introduction}

Rock glaciers are thick, lobate or tongue-like masses of angular debris that move slowly down slope as a consequence of the deformation of internal ice or frozen sediment. Two main categories can be distinguished. Protalus rock glaciers form through the deformation of talus containing interstitial ice derived from meteoric water and form step-like or lobate extensions of the lower parts of talus slopes. The formation and development of these permafrost phenomena are independent of glacier ice. A strong association occurs with protalus rock glaciers and permafrost and limited snowfall, suggesting that protalus rock glaciers have the potential for the recon-

\footnotetext{
* Corresponding author.
}

struction of palaeoclimatic conditions (Vitek and Giardino, 1987; Ballantyne and Harris, 1994). The second type, morainic rock glaciers, form through the burial and subsequent deformation of glacier ice under a thick cover of rock debris. Morainic rock glaciers commonly form in response to ice retreat, when thick debris accumulates on the terminus of a glacier and provides insulation and overburden pressure, which allows that debris to be remobilized downvalley. Permafrost is required for the maintenance of the ice-core throughout the history of the rock glacier. The debris commonly extends from recognizable moraines marking the former limit of an ice margin. The resulting 'morainic rock glacier' commonly exhibits arcurate ridges and troughs at the surface, and may contain multiple lobes representing different intervals of activity or different rates of 
flow occurring simultaneously. A continuum of forms, however, exists between morainic and protalus rock glaciers, which complicates the study and use as palaeoclimatic indicators (Giardino and Vitek, 1988). Both types of rock glaciers are important in the transportation of substantial amounts of rock debris and constitute important geotechnical problems/hazards. In some mountain regions, rock glaciers are intimately associated with mass movements such as landsliding and rock avalanching (Evin, 1987; Johnson, 1987; Olyphant, 1987; Shakesby et al., 1987; Shroder, 1987; Vick, 1987). A better understanding of rock glaciers is important because it is possible to confuse them with morphologically similar landforms resulting from quite distinct processes such as landsliding. Some landslides are directly relevant to the formation of rock glaciers because they bury glaciers and provide large amounts of supraglacial debris which can eventually become a rock-glacier.
Rock glaciers and rock glacierised slopes are present at high elevations throughout the western Himalayas and Karakoram Mountains in northern Pakistan and India. The occurrence has been briefly mentioned (Hewitt, 1989, 1993; Owen, 1989, 1991; Owen et al., 1995; Owen and Derbyshire, 1989, 1993; Sharma and Owen, 1996; Shroder, 1993); however, the significance and distribution have never been examined in detail. This paper will examine the characteristics and distribution of rock glaciers in the Karakoram Mountains and northern India to highlight importance as geomorphological agents and to assess geomorphological significance.

\section{Methods}

The distribution of rock glaciers was mapped from 1985 to 1995 and selected examples were studied in detail (Fig. 1). Complete coverage of the

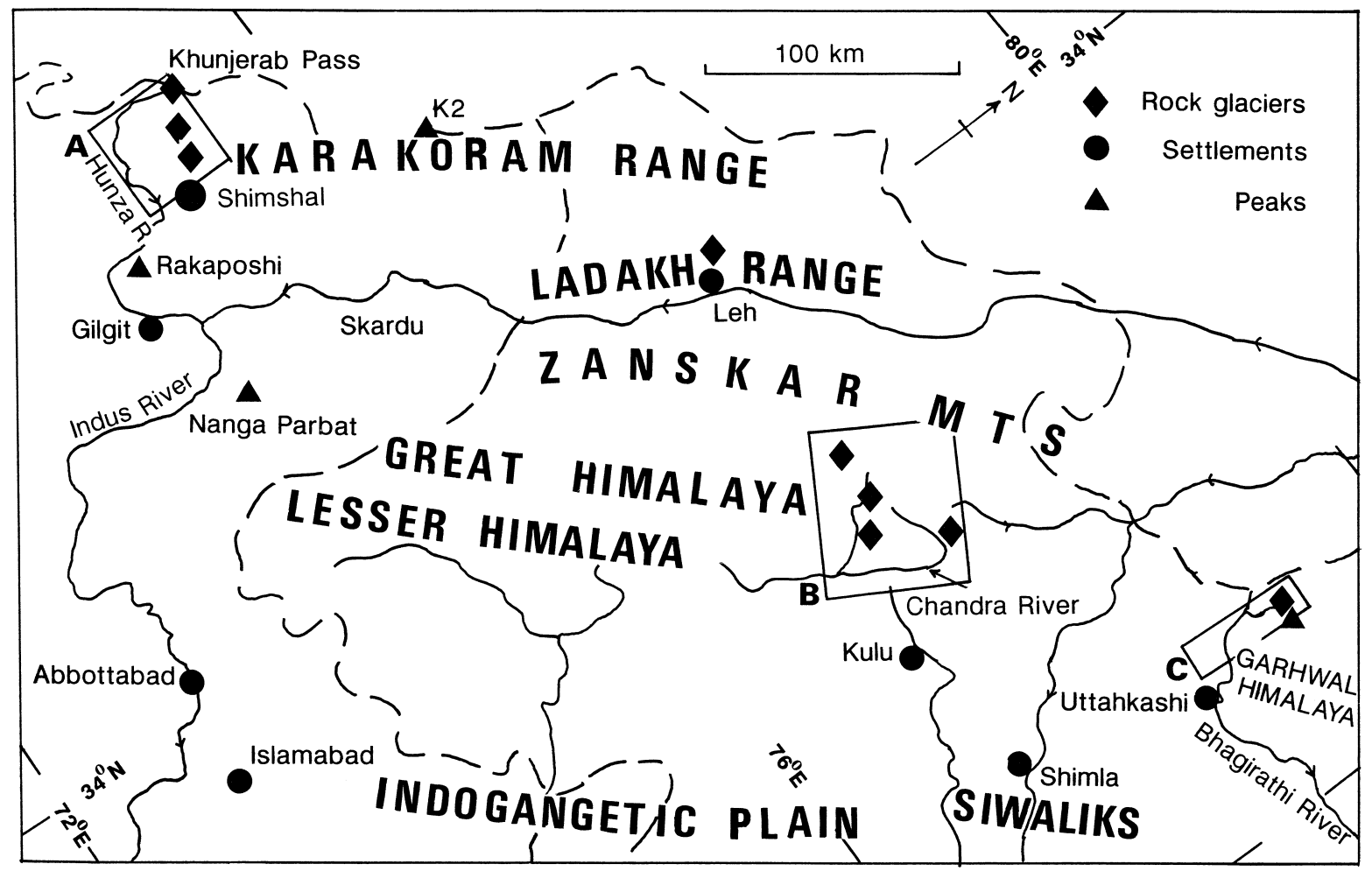

Fig. 1. Location of detailed study areas and the distribution of known rock glaciers in the Himalaya and Karakoram Mountains of northern Pakistan and India. (A) Karakoram Mountains, northern Pakistan; (B) Lahul Himalaya; (C) Garhwal Himalaya. 


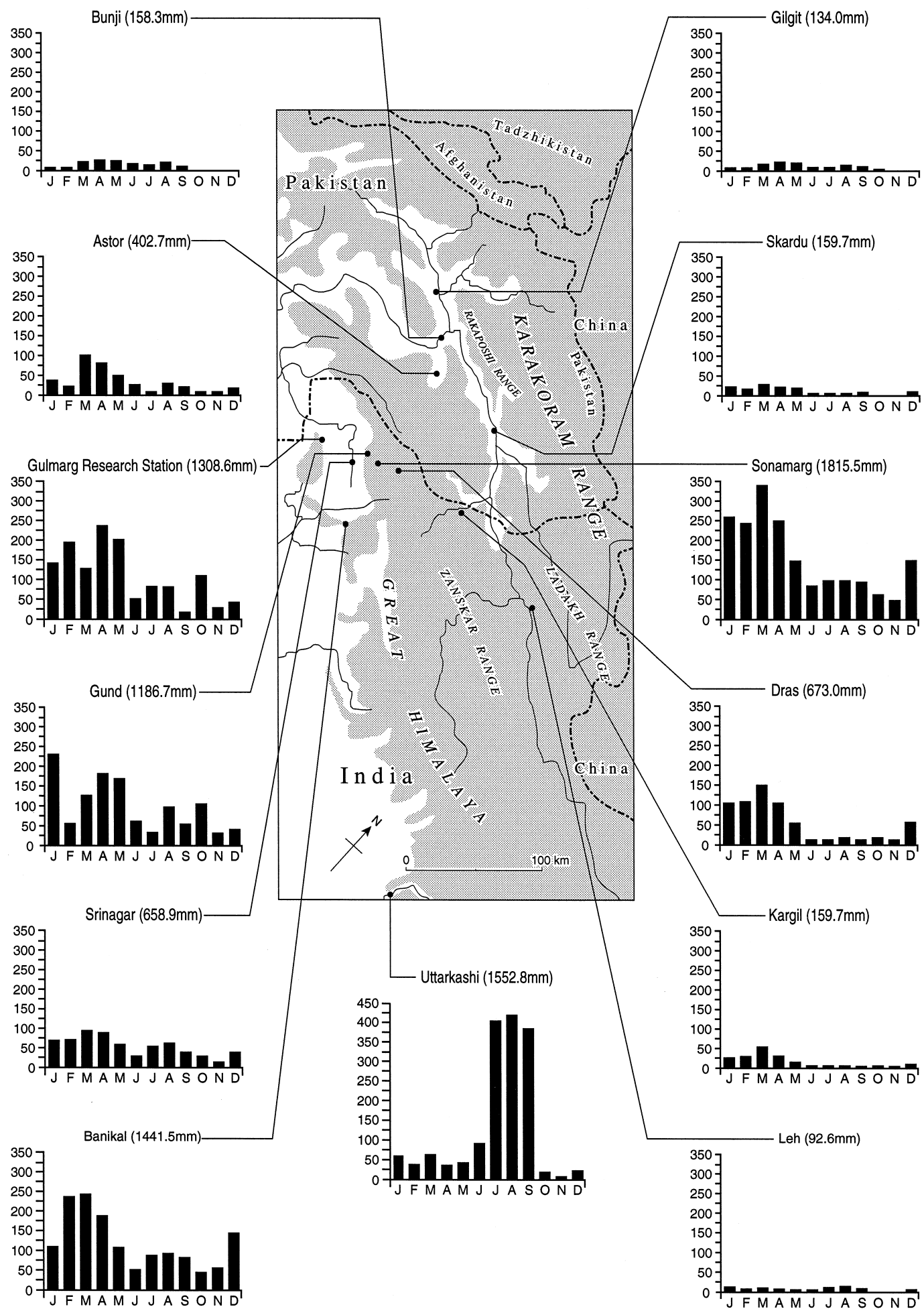

Fig. 2. Characteristics of precipitation for the mountains of northern Pakistan and India. 
western Himalayas and the Karakoram Mountains was not possible because of logistical problems; however, three main areas were examined: the Garhwal and Lahul Himalaya (India); and the Karakoram Mountains (northernmost Pakistan). These three regions provide examples of different climatic conditions, increasing in aridity from Garhwal, then Lahul, and finally to northernmost Pakistan. Geomorphological maps were constructed at scales ranging form $1: 10,000$ to $1: 50,000$, and geomorphological and sedimentological observations were recorded.

\section{Geomorphological setting}

Tectonically, the mountains of the Himalayas and Karakoram represent the inter-continental collision of the Indian and Asian plates (Gansser, 1964; Dewey and Burke, 1973). This tectonism has resulted in a series of arcuate mountain belts that trend approximately east-west, and rise in elevation from south to north, i.e., from the Indo-Gangetic Plains across the Siwaliks, the Lesser Himalayas (including the Pir Panjal), the Greater Himalayas, the Karakoram Mountains to the Tibetan Plateau. Climatic gradients also occur from west to east, and from south to north. The climate to the west is influenced more by the mid-latitude westerlies, whereas to the east it is strongly influenced by the southwest monsoon of the Indian sub-continent. Hence, a substantial decrease in annual rainfall occurs across the Himalayas from the east (e.g., Jalpaiguri, at the foot of the Himalaya near Darjeeling receives $>3500 \mathrm{~mm} \mathrm{a}^{-1}$ ) to the west (e.g., Kashmir receives $<1500 \mathrm{~mm} \mathrm{a}^{-1}$ ). A substantial decrease in precipitation occurs northwards across the Himalayas that results from orographic effects which produce a 'rainshadow' to the north. These precipitation characteristics are shown for northern Pakistan and northern India (Fig. 2). The Himalayas also display a strong vertical zonation of climate, with an environmental lapse rate of $\sim 1^{\circ} \mathrm{C}$ per $270 \mathrm{~m}$ up to $1500 \mathrm{~m}$ asl (Singh and Singh, 1987) which increases to $\sim 1^{\circ} \mathrm{C}$ per $170 \mathrm{~m}$ at higher altitudes (Derbyshire et al., 1991). Precipitation increases with altitude, up to about $3000 \mathrm{~m}$ asl, and then decreases with increasing altitude (Ives and Messerli, 1989). The annual precipitation recorded at
$2750 \mathrm{~m}$ asl on the southern slopes of the Himalayan mountains is $\sim 2800 \mathrm{~mm}$. This decreases sharply to $\sim 940 \mathrm{~mm}$ at $3400 \mathrm{~m}$ asl, and to $\sim 580 \mathrm{~mm}$ at 4400 $\mathrm{m}$ asl (Ives and Messerli, 1989). On the northern side of the Himalayas, annual precipitation at $5000 \mathrm{~m}$ asl is reduced to $335 \mathrm{~mm}$, with an additional decrease to

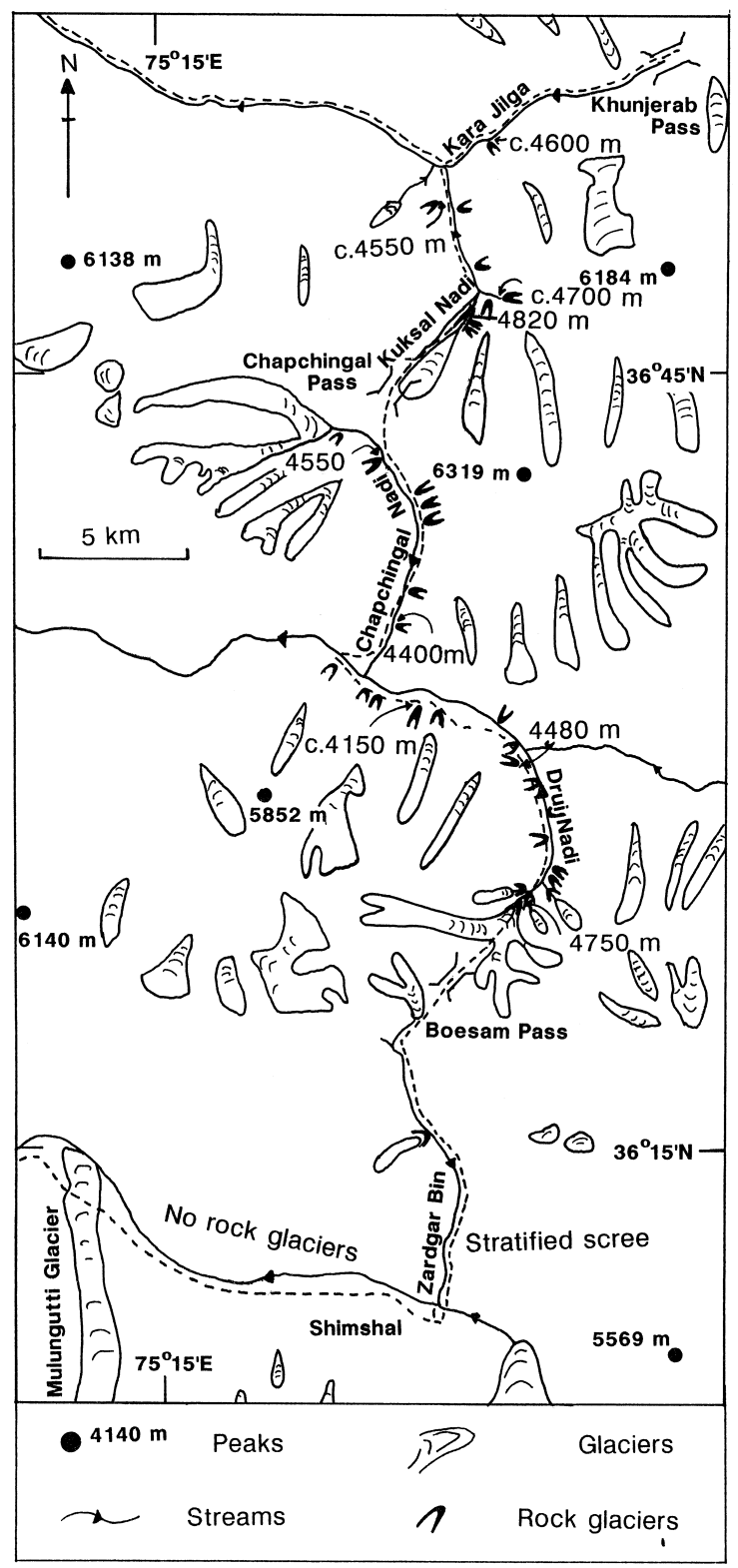

Fig. 3. Map of a transect from Shimshal to the Khunjerab Pass in Northern Pakistan. The crescent shapes represent the toes of rock glaciers. 
$240 \mathrm{~mm} \mathrm{a}^{-1}$ further north in Tibet (Zheng, 1989). Therefore, precipitation decreases by an order of magnitude from the southern Himalayas to Tibet.

In this study, the Garhwal Himalaya is the wettest area because of effect of the summer monsoon. Mean annual precipitation is $>1500 \mathrm{~mm} \mathrm{a}^{-1}$ in Uttahkashi and decreases northwards to $<1000 \mathrm{~mm}$ $\mathrm{a}^{-1}$ north of Gangotri (Sharma, 1996). The valley floors in the Karakoram Mountains constitute the driest area of the transect with the mean annual precipitation being $<150 \mathrm{~mm} \mathrm{a}^{-1}$, although this increases with altitude (Goudie et al., 1984). The Lahul Himalaya is transitional between these two moisture regimes (Owen et al., 1995).

Vegetation, controlled altitudinally and latitudinally within the mountain belt, becomes progressively more constrained to the north and to the west by increased aridity (Paffen et al., 1956; Schweinfurth, 1968; Singh and Singh, 1987; Owen et al., 1995). In the Karakoram Mountains, along the tran-

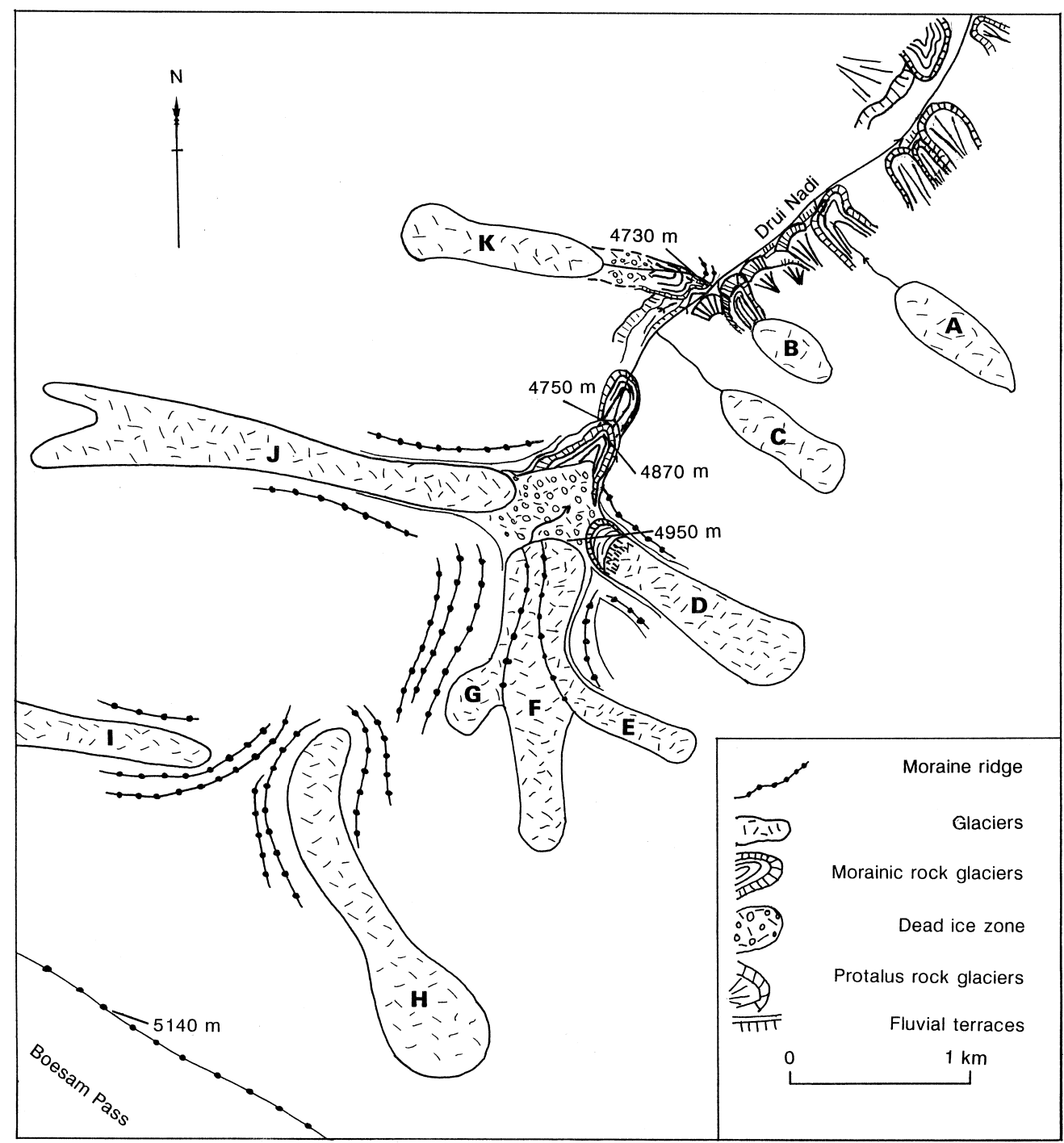

Fig. 4. Geomorphological map of the Drui Nadi (valley) in Northern Pakistan. The glaciers in this region are not named; therefore, they have been given letters A to $\mathrm{K}$ for clarity. 
sect shown in Fig. 2, trees are exceedingly rare and areas without vegetation are widespread.

All three study areas have high relative relief with slopes rising from $\sim 1500 \mathrm{~m}$ to more than $6000 \mathrm{~m}$ asl. The valley floors are dominated by alluvial fans and extensive fluvial and glaciofluvial outwash, whereas the bedrock slopes are mantled intermittently by remnant moraines, lacustrine sediments, debris flow cones and widespread scree. The highest elevations are often snow covered (Owen, 1988; Owen et al., 1995; Sharma, 1996). Glaciers within these regions are among the longest outside the polar regions. They exhibit steep surface slopes, have high accumulation areas, and are characterized by high activity indices (Owen and Derbyshire, 1989; Owen et al., 1995; Sharma and Owen, 1996). The regions are drained by some of the greatest rivers in the world. In the Karakoram Mountains, these include the Gilgit, Hunza and Indus Rivers. The Lahul Himalaya is drained by the Chandra River and the Garhwal Himalaya, by the Bhagirathi River, considered to be the source of the Ganges.

The Quaternary glacial histories of these regions are discussed in Derbyshire et al. (1984) and by Shroder et al. (1993) for the Karakoram Mountains in northern Pakistan, in Owen et al. (1996) for the Lahul Himalaya, and in Sharma and Owen (1996) for the Garhwal Himalaya. These regions have experienced several glaciations during the Pleistocene and several minor advances during the Holocene, although absolute dating of glacial chronologies is presently unavailable. In each of the study regions, an early or mid-Holocene glacial advance has been recognised, extending several kilometres from present positions. This is called the Batura Glacial Stage in northern Pakistan, the Shivling Glacial Advance in Garhwal and, tentatively, the Sonapani I Advance in the Lahul Himalaya (Shroder et al., 1993; Owen et al., 1996; Sharma and Owen, 1996). The Sonapani I Advance, however, may date to the Little Ice Age (Owen et al., 1996). In northern Pakistan and Garhwal, the Pasu I Glacial Stage and the Bhujbas Glacial Advance, respectively, have been attributed to the Little Ice Age (LIA) (Shroder et al., 1993; Sharma and Owen, 1996; Grove, 1988) when glaciers advanced 1 or $2 \mathrm{~km}$ beyond present margins. Advances late in the 18th century have been recognised in the northern Pakistan (the Pasu II Glacial Stage) and in Lahul (Sonapani II Glacial Advance) (Shroder et al., 1993; Owen et al., 1996). During this period, glaciers advanced a few hundred metres from present positions. Correlations between these regions remains tentative, however, because of limited dating control.

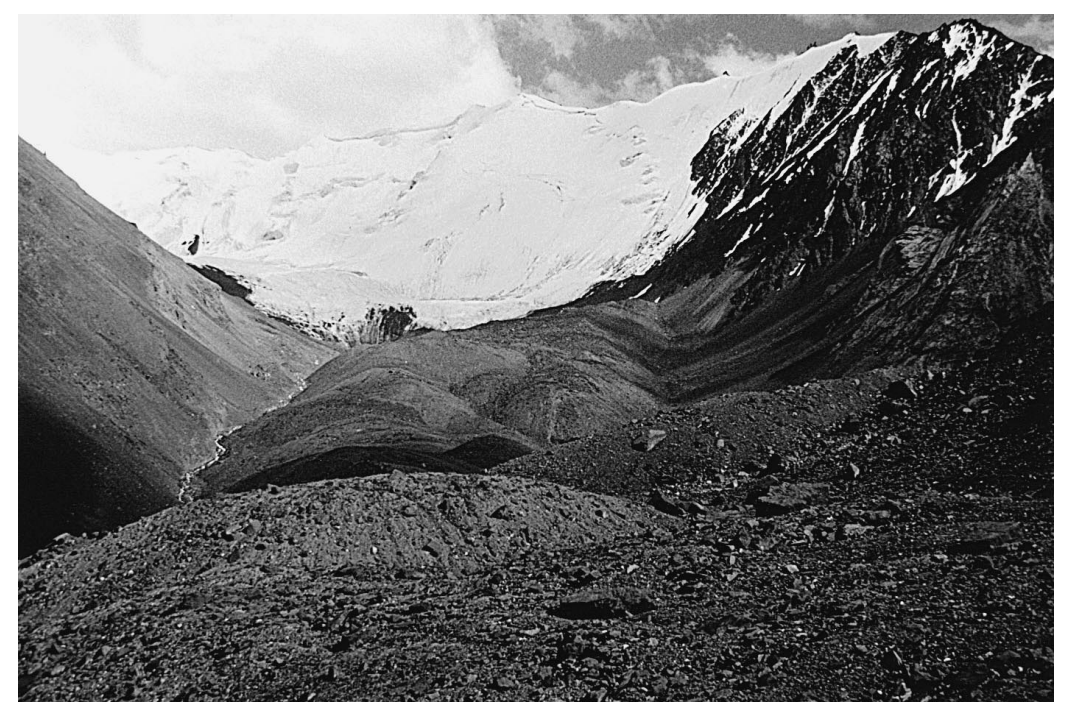

Fig. 5. View looking east up Glacier D in the Drui Nadi (valley), showing the region with a rock glacier beneath the contemporary glacier. 
The areas described within this paper provide an opportunity to examine rock glaciers within different climatic and geomorphological settings. This investi- gation is useful for comparing the nature of rock glaciers and formation at the western end of the Himalayan mountain belt.

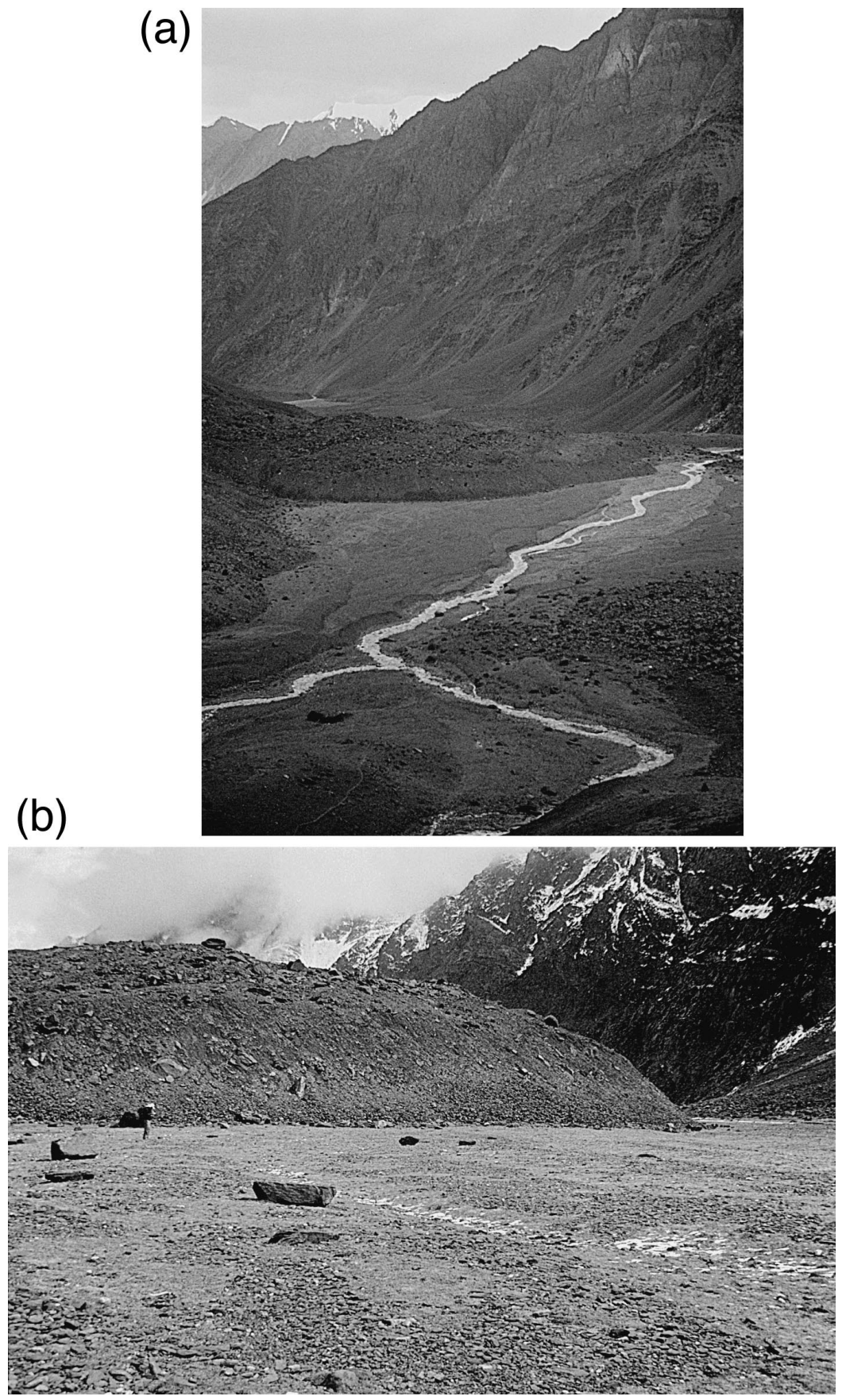

Fig. 6. Views of a rock glacier which has advanced down valley of Glacier K into the Drui Nadi (valley) looking N, A) down the Drui Nadi valley and $\mathrm{B}$ ) at the margin of the rock glacier showing the over ridden river terraces. 


\section{Rock glaciers in the Karakoram Mountains and Himalayas of Pakistan and India}

The distribution of protalus and morainic rock glaciers, present in the Karakoram Mountains and Himalayas of Pakistan and northern India, is shown in Fig. 1.

\subsection{Karakoram Mountains, northern Pakistan}

Modern descriptions of rock glaciers in northern Pakistan are available from the eastern side of Kara Jilga, $\sim 10 \mathrm{~km}$ southeast of the Khunjerab Pass (Owen, 1988: Fig. 1). Another investigated rock glacier originates from the southern lateral moraine of Sachen Glacier, descending the eastern slope of Nanga Parbat (Owen, 1988; Owen and Derbyshire, 1989; Shroder, 1993). The largest rock glaciers observed at present occur between Shimshal and the Khunjerab Pass (Fig. 3) and are best developed along the Drui Nadi (valley), north of Boesam Pass (Fig. 4). The rock glaciers here are derived from prominent moraines from which the local glaciers have recently retreated. Fig. 5 shows the characteristics of the main valley rock glacier which is advancing northwards down the Drui Nadi (valley). The extent of this advance is recorded by the distance between the current terminus of the rock glacier and the point of closure in the outermost lateral moraines upvalley that mark the position of the former glacier, from which the rock glacier is advancing. This distance is at least $0.5 \mathrm{~km}$, and the outermost margin of the rock glacier is presently $\sim 90 \mathrm{~m}$ high and is overriding vegetated terrain and bedrock with desert varnish. Buried vegetation, exhumed from $0.5 \mathrm{~m}$ inside the margin, will provide a maximum age for the recent advance of the rock glacier once dated. Similar rock glaciers debouch into Drui Nadi from adjacent tributary valleys (Figs. 6 and 7), some crossing recent fluvial terraces (some only $\sim 4 \mathrm{~m}$ above the modern stream). In some cases, the rock glaciers reach the modern river (near the confluence with Chapchingal Nadi, see Fig. 3). Some of the recent fluvial terraces are up to $200 \mathrm{~m}$ wide and are locally buried by rock glaciers that have advanced across them. Many of the rock glaciers are between $1 \mathrm{~km}$ to $\sim 2 \mathrm{~km}$ long and $0.3 \mathrm{~km}$ wide and have multiple lobes and troughs up to $15 \mathrm{~m}$ in relief. These extend down to elevations of between approximately $4800 \mathrm{~m}$ to $4500 \mathrm{~m}$ asl.

Most commonly, rock glaciers in the Karakoram Mountains have formed downvalley of former end

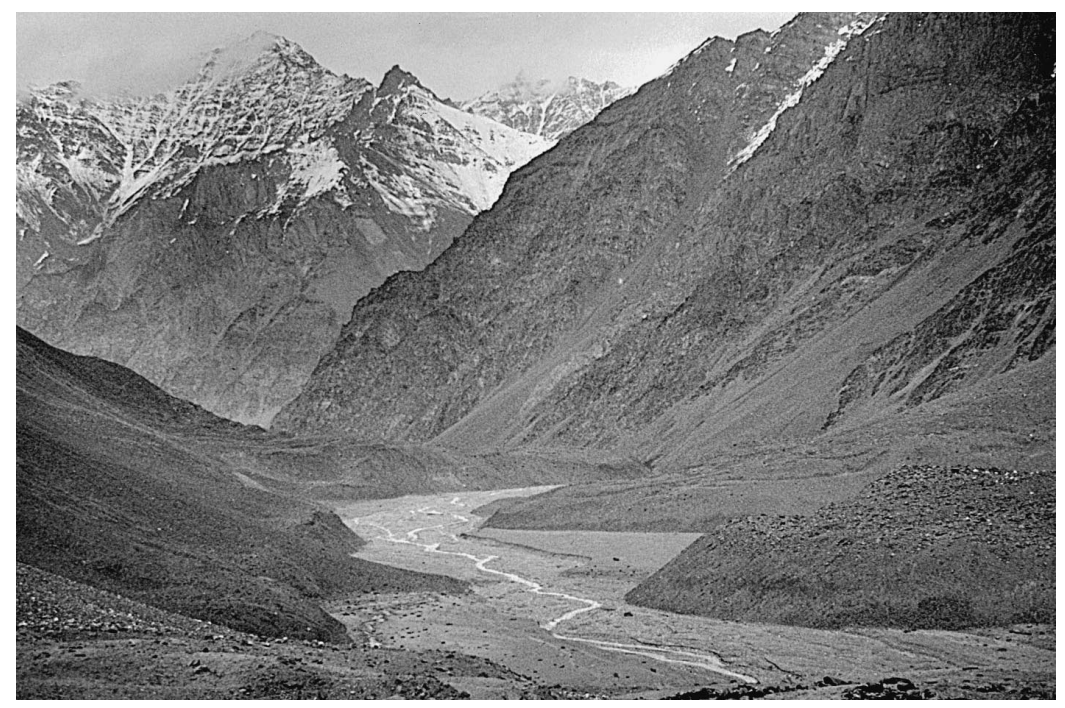

Fig. 7. View NE down the northern end Drui Nadi valley looking at rock glaciers, which override river terraces. 


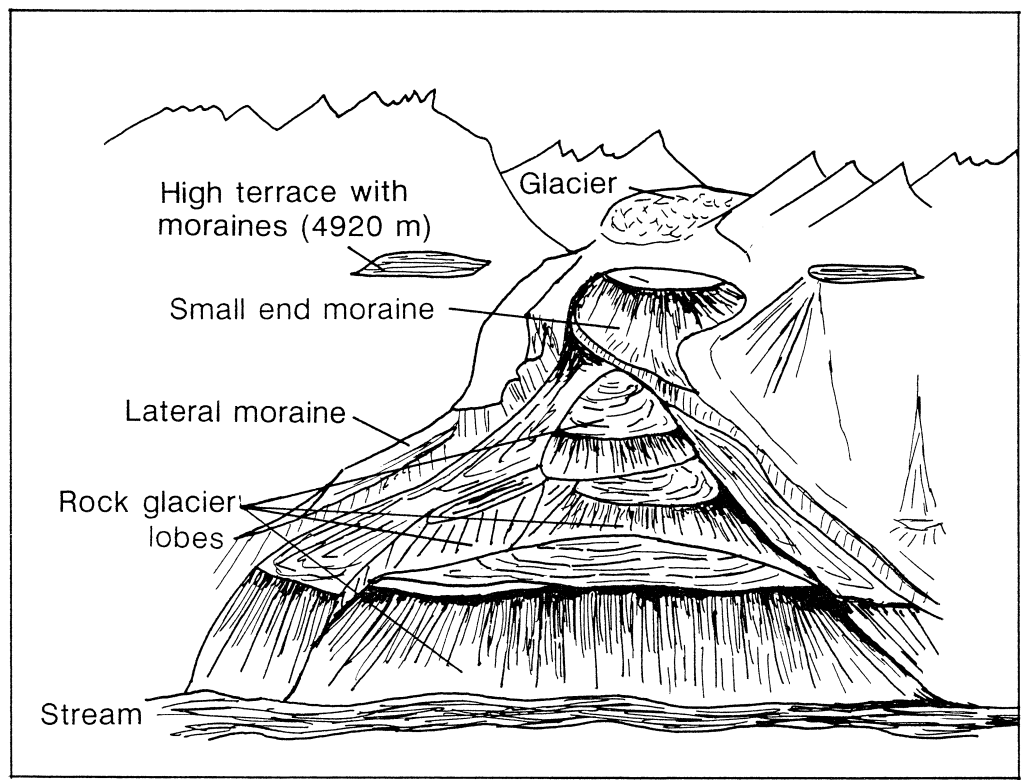

Fig. 8. View of rock glacier and associated moraines as well as the contemporary glacier on the western side of the Chapchingal Nadi (valley) immediately SW of the Chapchingal Pass.

moraines (as illustrated in Fig. 8) left by recent ice retreat. Most glaciers are now several hundred metres up valley from these end moraines. At most locations, superimposed lobes on the rock glaciers record several generations of activity and/or different sectors of activity on the same lobe (see Fig. 9, the Kuksal Nadi). The massive nature of these rock glaciers (commonly $>15 \mathrm{~m}$ thick) and the steep margins indicate a sizeable thickness of burried ice.

Protalus rock glaciers are also present in the Duri Nadi (valley), but development is restricted to the eastern slopes, which range from about 25 to $35^{\circ}$

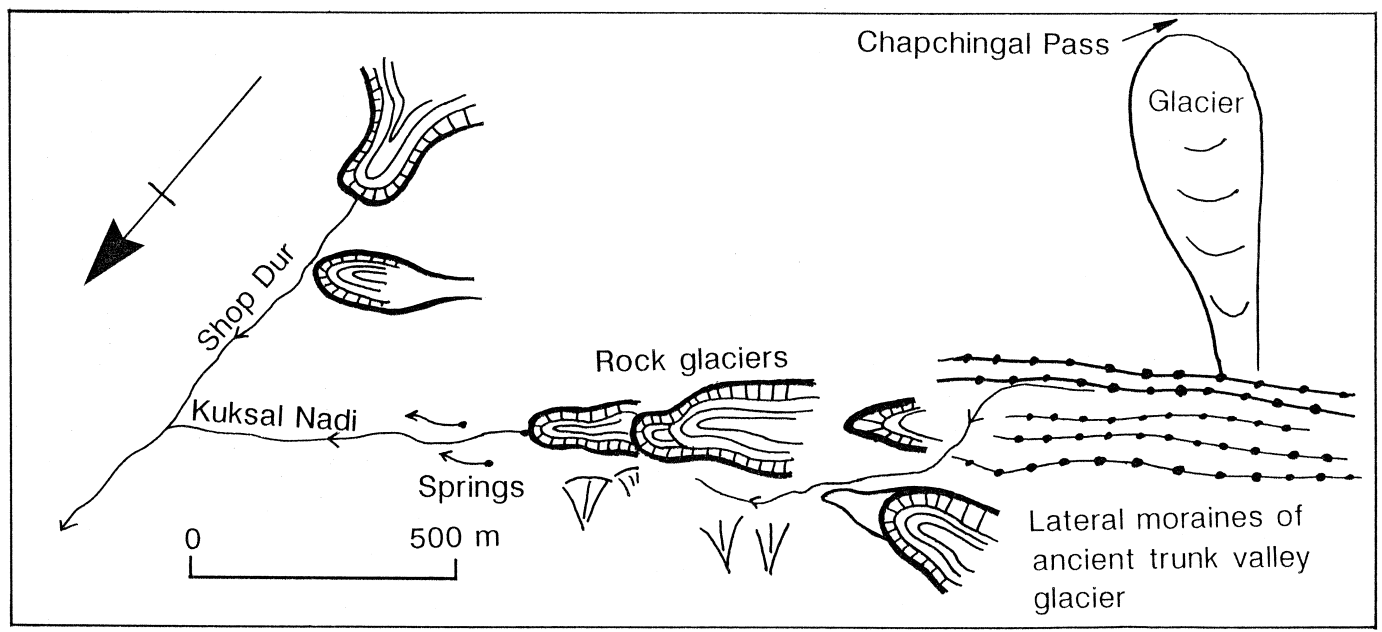

Fig. 9. Sketch map of the Kuksal Nadi (valley) showing several generations of rock glaciers. 


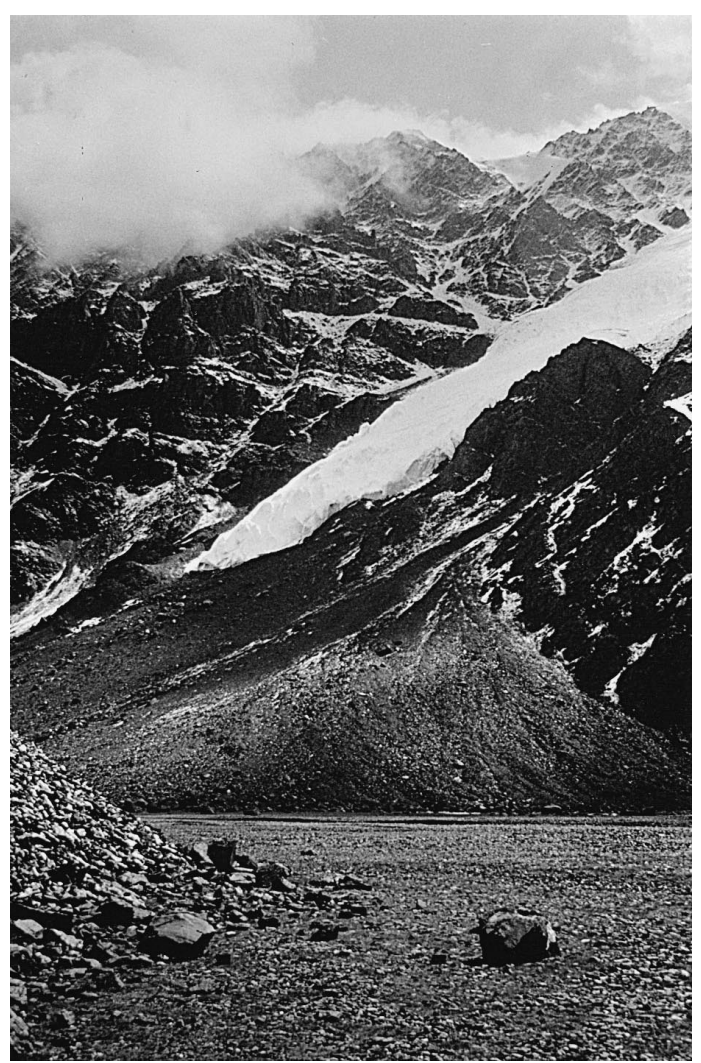

Fig. 10. Views looking east of Glacier B in the Drui Nadi (valley), showing the early stages in the development of a rock glacier.
(Fig. 10). These rock glaciers are unrelated to former valley glaciers, and are restricted to the base of local talus slopes, where they are building onto the valley floors. Some of these talus slopes terminate above small, coalescent rock glaciers which display arcurate ridges and troughs with terminal slopes 5-10 m high. Occasionally, levees upslope indicate additional sediment supply from debris flows or avalanches. These smaller rock glaciers are considered to represent the protalus vs. morainic category.

\subsection{Lahul Himalaya}

The rock glaciers in this region were first described in the Milang valley by Owen et al. (1995). Both protalus and morainic rock glaciers occur in the Milang valley, while elsewhere morainic types dominate evolving from thinning debris-covered glaciers (Owen et al., 1995).

The rock glaciers are most abundant on north-facing slopes above the Milang Valley and the upper Bhaga valley. In the Milang valley, the rock glaciers descend to approximately $3800 \mathrm{~m}$ asl, whereas in the upper Bhaga valley they descend to approximately $4100 \mathrm{~m}$ asl. Rock-glacierised slope deposits, forming protalus rock glaciers, are also present and occur at

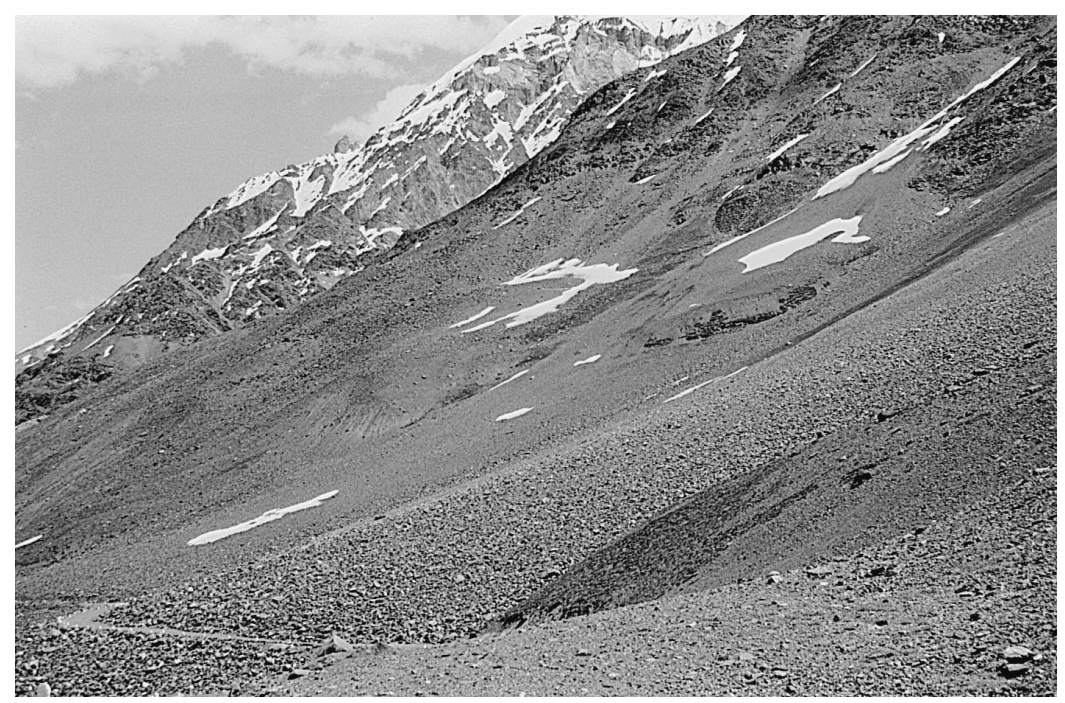

Fig. 11. Protalus rock glacier (central left) and screes in the upper Bhaga valley. 


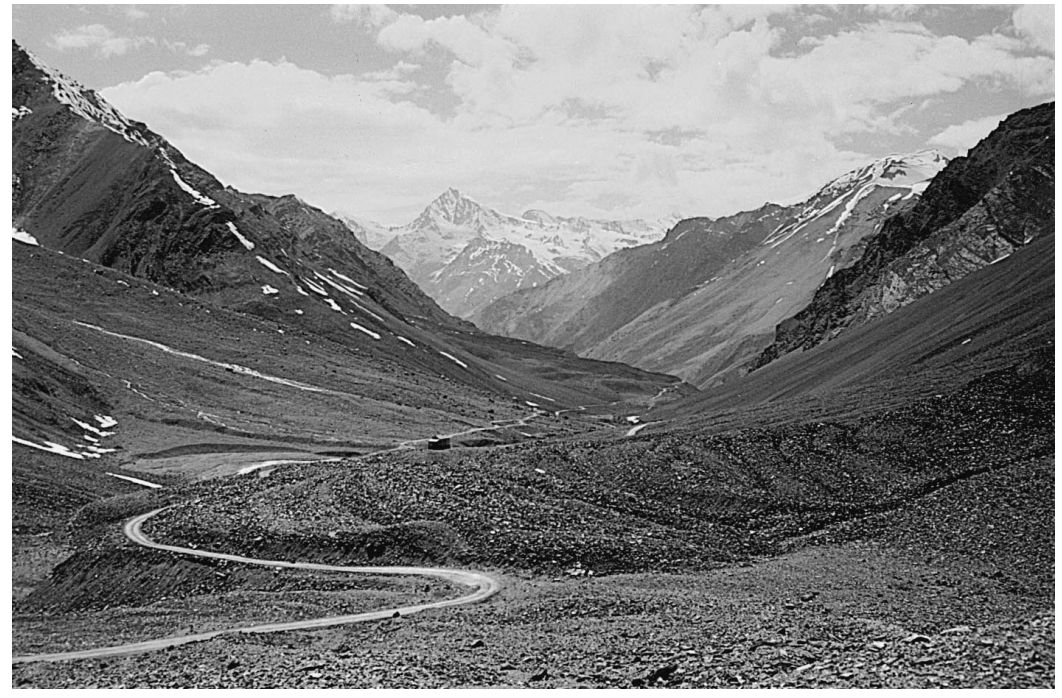

Fig. 12. A well-developed protalus rock glacier in the upper Bhaga valley.

altitudes of approximately $4000 \mathrm{~m}$ asl in the upper Bhaga and Chandra valleys, and above $3650 \mathrm{~m}$ in the Kulti Nala valley. In the upper Bhaga valley, protalus rock glaciers are particularly well developed (Figs. 11 and 12). These are characterised by arcurate ridges and troughs with relief between 5 and 10 $\mathrm{m}$, and are associated with talus slopes.
The rock glaciers in this region are morphologically complex, comprised of an assemblage of lobes resulting from differential movement. Many rock glaciers are advancing from cirques that supply abundant debris by rockfall and avalanche processes. The surface of the rock glaciers is commonly stepped with a number of lateral ridges, which display com-

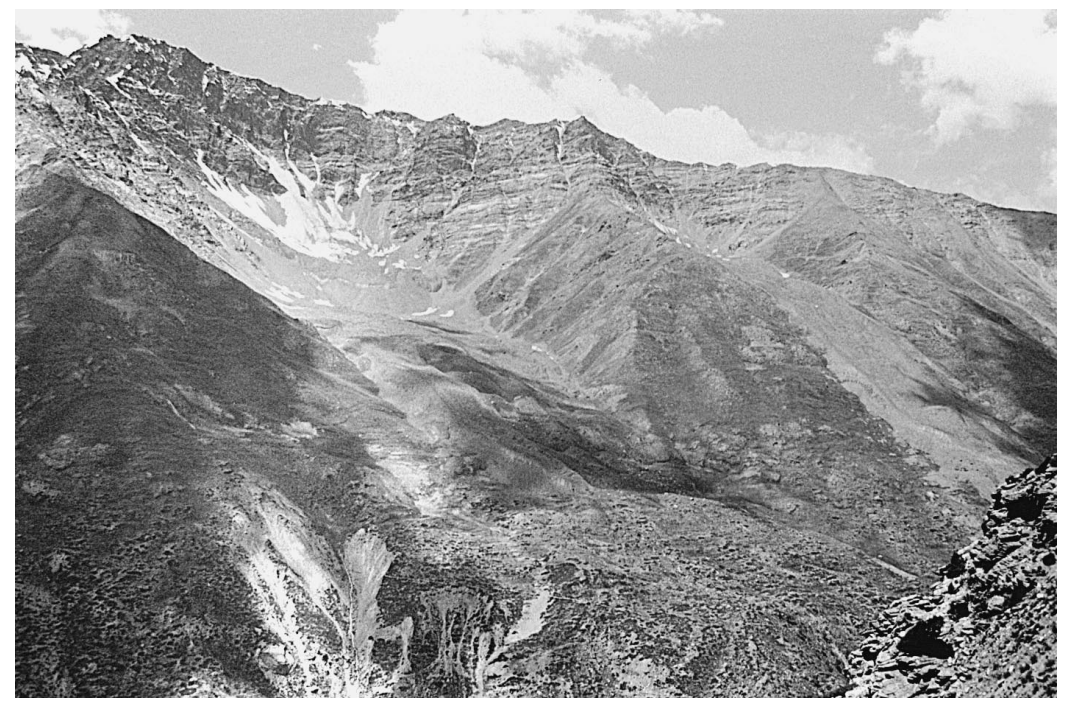

Fig. 13. View looking SW at a rock glacier in the Milang valley. 


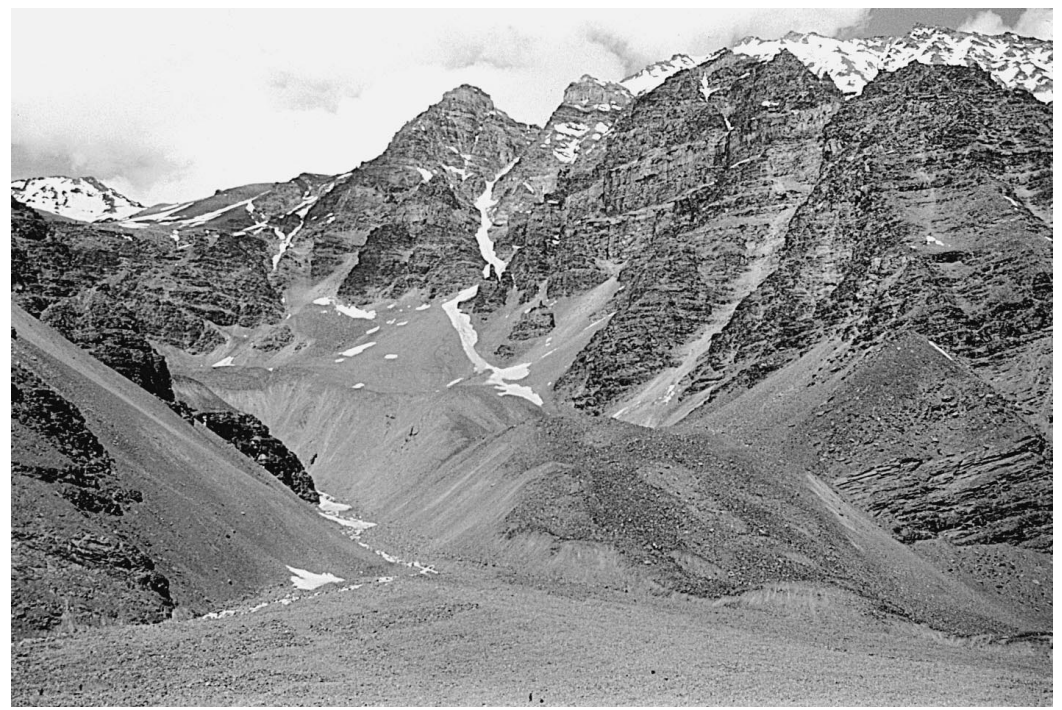

Fig. 14. Rock glacier associated in a glaciated valley in the upper Bhaga valley.

pressive folds in the lower reaches, as well as lateral shears along the margins where boulders are vertically oriented. The lobe fronts form unvegetated slopes up to $60 \mathrm{~m}$ high, at angles up to $60^{\circ}$, and are subject to frequent collapse by mass movement pro- cesses such as rock sliding and rock falls (Figs. 13 and 14). These processes indicate rapid advance of rock glaciers and transport of sediment. Some rock glaciers appear to overlie older rock glaciers, documenting separate intervals of rock glacier formation.

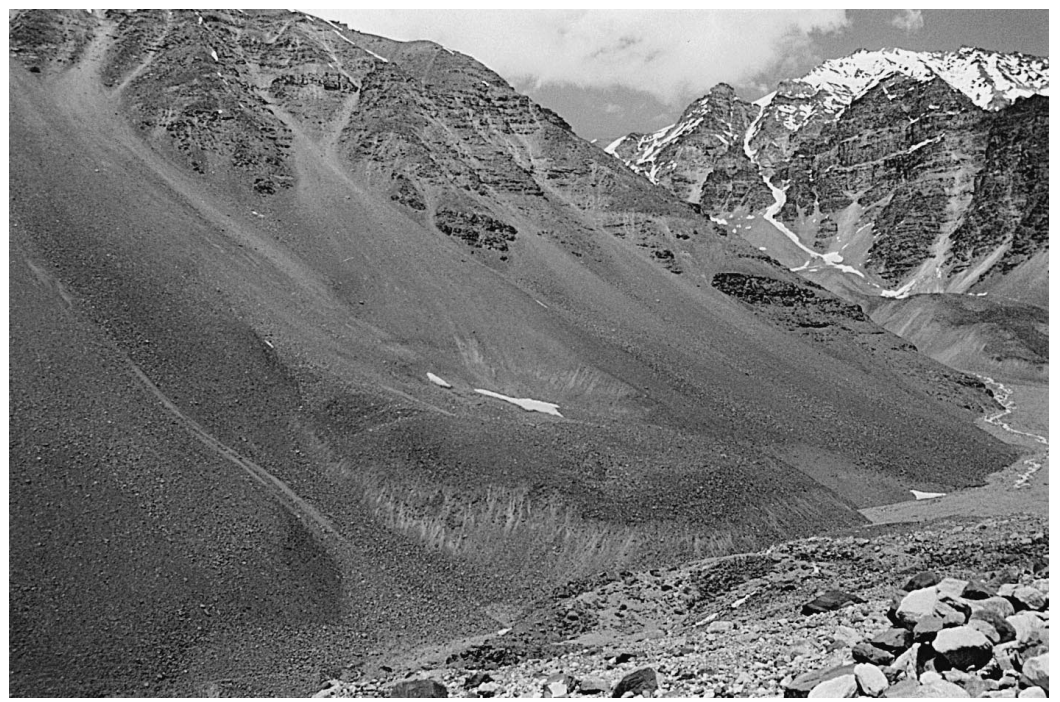

Fig. 15. Rock glacier at the head of a glaciated tributary valley in the upper Bhaga valley. 
Other rock glaciers are present at the heads of small tributary valleys where they are deeply incised by streams and extend from lateral moraines (Fig. 15).

\subsection{Garhwal Himalaya}

The protalus and morainic rock glaciers that are present in this region are the least developed within the three study areas. They occur only in the northernmost part of Garhwal, in the upper Bhagirathi valley, above $4000 \mathrm{~m}$ asl. The morainic rock glaciers are associated with large end and lateral moraines, whereas the protalus rock glaciers are associated with talus cones which surmount the valley sides in the glaciated catchments (Fig. 16).

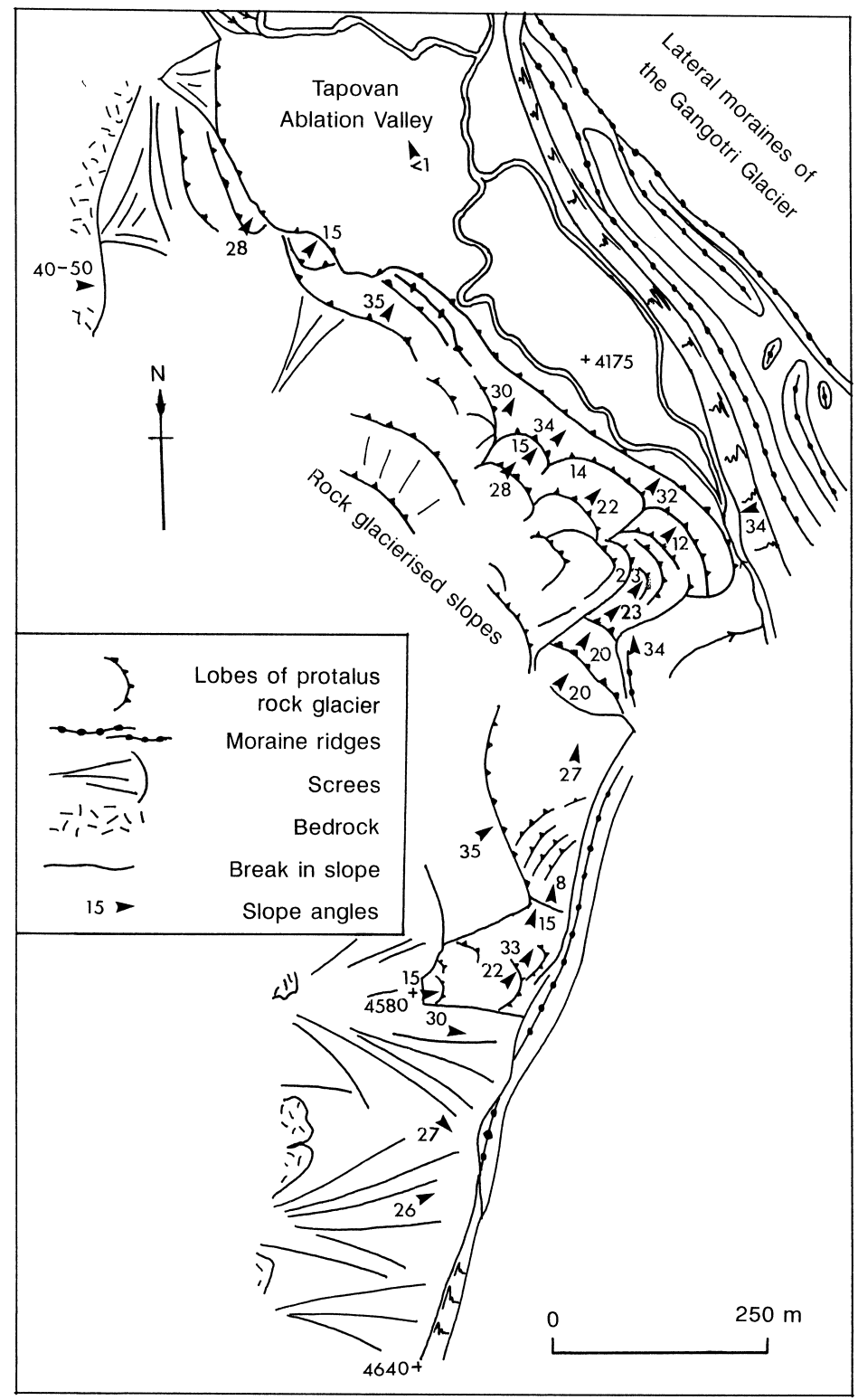

Fig. 16. Slopes with rock glaciers above the Gangotri Glacier in Garhwal. 


\section{Discussion}

The distribution of morainic rock glaciers in northern India and Pakistan is controlled by altitude and aridity. Rock glaciers develop in regions $>4000$ $\mathrm{m}$ asl, where annual precipitation is less than 1000 $\mathrm{mm} \mathrm{a}^{-1}$ (cf. Figs. 1 and 2). The high quantities of rock fall and avalanche debris produce large concentrations of supraglacial debris on most glaciers within the High Himalayas and Karakoram Mountains and contribute to widespread development of rock glaciers following ice retreat. In contrast, rock glaciers are absent within the monsoon-influenced Lesser Himalaya because of the exclusion of permafrost. Poorly developed rock glaciers are present in Garhwal and southern Lahul, whereas in Lahul, Ladakh and northernmost Pakistan, rock glaciers become a dominant component of the landscape. The distribution of rock glaciers is largely controlled by elevation because they require permafrost to remain active, maintaining interstitial or buried ice. The absence of rock glaciers at lower elevations, or in areas of higher precipitation $\left(>1000 \mathrm{~mm} \mathrm{a}^{-1}\right)$, simply records a positive annual energy balance in the subsurface that removes or precludes the formation of ice, terminating or preventing rock glacier activity. Hence, in the Himalaya, rock glacier activity is favoured by higher elevation and lower precipitation, which allows the maintenance of permafrost. Contemporary active and inactive rock glaciers, therefore, provide a minimum estimate on the lower limit of modern and past permafrost.

The youthfulness and active nature of the rock glaciers in this region are recorded by the advance over recent fluvial terraces and modern floodplains. These rock glaciers record recent and widespread ice retreat during late Holocene times, and likely since the Little Ice Age at the turn of this century. In Lahul, it is likely that the ice-cored moraines became rock glacierised after the Sonapani I Glacial Advance, that has been attributed to the Little Ice Age by Owen et al. (1996). Similar responses are recorded in the Karakoram Mountains where rock glaciers are still advancing beyond the limits of ice-cored end moraines (Fig. 8). These end moraines are probably equivalent the Pasu I Glacial Stage moraines of Derbyshire et al. (1984), which are attributed to the Little Ice Age. This suggests a somewhat similar pattern of formation to that of Lahul. Increased moisture during the Pasu I stage allowed glaciers to advance, after which the region became more arid. As glaciers retreated, moraines that contain buried ice begin to be mobilised to form rock glaciers. Alternatively, the end moraines may be older than Pasu I, and might represent an earlier period of climate change, possibly during mid-Holocene times.

\section{Conclusions}

Rock glaciers in northern India and Pakistan are restricted climatically and altitudinally to regions with an annual precipitation less than $1000 \mathrm{~mm}$ and altitudes above $4000 \mathrm{~m}$ asl. Formation requires the existence of permafrost and most rock glaciers record the advance of ice-cored moraines following the retreat of glaciers soon after the LIA. The youthfulness of these feature are recorded by the advance over fluvial terraces bordering modern floodplains, and onto these floodplains and vegetated terrain.

This study highlights the abundance and importance of rock glaciers in the high mountains of northern Pakistan and India where they constitute a highly active component of the landscape. Because of continued activity and size, rock glaciers should be regarded as an important mechanism of sediment transport in these areas. The understanding of rock glaciers is relevant to the history of permafrost, the transport of sediment, and the evolution of high mountain landscapes.

\section{References}

Ballantyne, C., Harris, C., 1994. The Periglaciation of Great Britain. Cambridge Univ. Press, Cambridge.

Dewey, J.F., Burke, C.A., 1973. Tibetan, Variscan and Precambrian basement reactivation products of continental collision. J. Geol. 81, 683-692.

Derbyshire, E., Jijun, L., Perrot, F.A., Shuying, X., Waters, R.S., 1984. Quaternary glacial history of the Hunza valley Karakoram Mountains, Pakistan. In: Miller, K. (Ed.), International Karakoram Project. Cambridge Univ. Press, Cambridge, pp. 456-495.

Derbyshire, E., Yafeng, S., Li, J., Zheng, B., Li, S., Wang, J., 1991. Quaternary glaciations of Tibet: the geomorphological evidence. Quaternary Sci. Rev. 10, 485-510. 
Evin, M., 1987. Lithology and fracturing control of rock glaciers in southwestern Alps of France and Italy. In: Giardino, J.R., Shroder, J.F., Vitek, J.D. (Eds.), Rock Glaciers. Allen and Unwin, London, pp. 83-106.

Giardino, J.R., Vitek, J.D., 1988. The significance of rock glaciers in the glacial-periglacial landscape continuum. J. Quaternary Sci. 3 (1), 97-104.

Gansser, A., 1964. Geology of the Himalayas. Wiley, Chichester, 289 pp.

Goudie, A.S., Brunsden, D., Collins, D.N., Derbyshire, E., Ferguson, R.I., Hashnet, Z., Jones, D.K.C., Perrott, F.A., Said, M., Waters, R.S., Whalley, W.B., 1984. The geomorphology of the Hunza Valley, Karakoram Mountains, Pakistan. In: Miller, K. (Ed.), International Karakoram Project. Cambridge Univ. Press, Cambridge, pp. 339-411.

Grove, J.M., 1988. The Little Ice Age. Methuen, 498 pp.

Hewitt, K., 1989. Altitudinal organisation of Karakoram geomorphic processes. Z. Geomorphol. 76, 9-32.

Hewitt, K., 1993. Altitudinal organisation of Karakoram geomorphic processes and depositional environments. In: Shroder, J.F. (Ed.) Himalayas to the Sea: Geology, Geomorphology and the Quaternary. Routledge, London, pp. 153-183.

Ives, J.D., Messerli, B., 1989. The Himalayan Dilemma: reconciling development and conservation. Routledge, London, 295 pp.

Johnson, P.G., 1987. Rock glacier: glacier debris systems or high magnitude low-frequency flows. In: Giardino, J.R., Shroder, J.F., Vitek, J.D. (Eds.), Rock Glaciers. Allen and Unwin, London, pp. 175-192.

Olyphant, G.A., 1987. Rock glacier response to abrupt changes in talus production. In: Giardino, J.R., Shroder, J.F., Vitek, J.D. (Eds.), Rock Glaciers. Allen and Unwin, London, pp. 55-64.

Owen, L.A., 1988. Terraces, uplift and climate in the Karakoram Mountains, Northern Pakistan. Unpublished PhD. University of Leicester, UK.

Owen, L.A., 1989. Terraces, uplift and climate in the Karakoram Mountains, Northern Pakistan: Karakoram intermontane basin evolution. Z. Geomorphol. 76, 117-146.

Owen, L.A., 1991. Mass movement deposits in the Karakoram Mountains and western Himalayas. Z. Geomorphol. 35 (4), 401-424.

Owen, L.A., Benn, D.I., Derbyshire, E., Evans, D.J.A., Mitchell, W.A., Richardson, S., 1996. The quaternary glacial history of the Lahul Himalaya northern India. J. Quaternary Sci. 11 (1), 25-42.

Owen, L.A., Benn, D.I., Derbyshire, E., Evans, D.J.A., Mitchell, W.A., Thompson, D., Richardson, S., Lloyd, M., Holden, C., 1995. The geomorphology and landscape evolution of the
Lahul Himalaya northern India. Z. Geomorphol. 39 (2), 145174.

Owen, L.A., Derbyshire, E., 1989. The Karakoram glacial depositional system. Z. Geomorphol. 76, 33-74.

Owen, L.A., Derbyshire, E., 1993. Quaternary and Holocene intermontane basin sedimentation in the Karakoram Mountains. In: Shroder, J.F. (Ed.), Himalayas to the Sea: Geology, Geomorphology and the Quaternary. Routledge, London, pp. 108-131.

Paffen, K.H., Pillewizer, W., Schneider, H.J., 1956. Forschungen im Hunza-Karakorum. Erdkunde 10, 1-33.

Schweinfurth, U., 1968. Vegetation of the Himalayas. In: Law, B.C. (Ed.), Mountains and Rivers of India. 21st International Geographical Congress, India, pp. 110-136.

Shakesby, R.A., Dawson, A.G., Matthews, J.A., 1987. Rock glaciers, protalus ramparts and related phenomena, Rodane, Norway: continuum of large-scale talus-derived landforms. Boreas 16, 305-317.

Sharma, M.C., 1996. Quaternary glacial history and landscape evolution of NW Garhwal, Central Himalaya. Unpublished $\mathrm{PhD}$ dissertation, Royal Holloway, Univ. of London.

Sharma, M.C., Owen, L.A., 1996. Quaternary glacial history of the Garhwal Himalaya India. Quaternary Sci. Rev. 15, 335365.

Shroder, J.F., 1987. Rock glaciers and slope failures: High Plateaus and La Sal Mountains, Colorado Plateau, UT, USA. In: Giardino, J.R., Shroder, J.F., Vitek, J.D. (Eds.), Rock Glaciers. Allen and Unwin, London, pp. 175-192.

Shroder, J.F., 1993. Himalaya to the sea: geomorphology and the Quaternary of Pakistan in the regional context. In: Shroder, J.F. (Ed.), Himalayas to the Sea: Geology, Geomorphology and the Quaternary. Routledge, London, pp. 1-42.

Shroder, J.F., Owen, L.A., Derbyshire, E., 1993. Quaternary glaciation of the Karakoram and Nanga Parbat Himalaya. In: Shroder, J.F. (Ed.), Himalayas to the Sea: Geology, Geomorphology and the Quaternary. Routledge, London, pp. 132-158.

Singh, J.S., Singh, S.P., 1987. Forest vegetation of the Himalaya. Botanical Rev. 53, 80-192.

Vick, S.G., 1987. Significance of landsliding in rock glacier formation and movement. In: Giardino, J.R., Shroder, J.F., Vitek, J.D. (Eds.), Rock Glaciers. Allen and Unwin, London, pp. 239-264.

Vitek, J.D., Giardino, J.R., 1987. Rock glaciers: a review of the knowledge base. In: Giardino, J.R., Shroder, J.F., Vitek, J.D. (Eds.), Rock Glaciers. Allen and Unwin, London, pp. 1-26.

Zheng, B., 1989. The influence of Himalayan uplift on the development of Quaternary glaciers. Z. Geomorphol. 76, 89116. 